\title{
The Impact of Applying Images on Knowledge of Affixes among EFL Learners
}

\author{
Fatemeh Sadat Nodjoomi \\ Islamic Azad University Roudehen Branch, Tehran, Iran \\ Ahmad Yaghoubi \\ Department of English Language Teaching, Roudehen Islamic Azad University, Roudehen, Iran
}

\begin{abstract}
The aim of the present study was to investigate the effect of Applying Images on Iranian EFL learners' Knowledge of Affixes. Based on a standard PET test, 60 learners selected out of 100 intermediate female EFL learners were chosen in the study. They were assigned randomly to one control and one experimental group. Then an affix test was given to them as a pretest. The experimental group received instruction through images as their treatment while the control group has their own way of teaching without treatment. After treatment, both groups were given an affix posttest again. The results were analyzed through sample independent $t$-test in order to see if there was any significant difference in the results. The results $(t=$ $8.245, p=0.000<0.001$ ) show that there is a significant difference between the scores of the two groups at the final exam. Thus, it is concluded that the participants of the experimental group strongly outperformed the control group in the final exam. The findings of this study have implications for students, teachers, and syllabus designers.
\end{abstract}

Index Terms - affixes, applying images, EFL learners

\section{INTRODUCTION}

Vocabulary learning is a key to language achievements, there is a constant way of learning new words and meaning for old words in a learner's first language (Decarrico, 2001). In learning new words, longterm retention received wide consideration as one of the greatest issues (Wei, 2007). If the learners cannot store new words immediately, they will forget them very soon. Different techniques have been proposed in methodology textbooks in order to facilitate vocabulary retention. According to Nation (2001), there are some reasons for the importance of vocabulary skills. First, vocabulary is crucial for improving reading comprehension. It is also believed there is strong association in a reading comprehension with the level of vocabulary knowledge (Nourie \& Davidson, 1992). Second, through vocabulary learning, learners can be successful in academic achievement. Thornbury (2002) states that "if you spend most of your time studying grammar, your English will not improve very much, but if you learn many words and expressions; you will see the most improvement" (p.114). Moreover, Readers who have known more vocabulary are more proficient that those who have limited number of vocabulary (O'Malley \& Chamot, 1990; Oxford, 1990).

Despite different ways that the teachers and learners use, learning vocabulary is truly challenging, so the best tools for improving vocabulary knowledge are strategies. According to Wenden (1991), "the learners use learning strategies in order to discover meaningful learning" (p.7).One of the most important strategies in vocabulary learning is using affixes knowledge (Bauer \& Nation, 1993; Nation, 1990). Based on Scalise (1984), "in order to form a new word , an affix is needed to be attached to a word" (p.79).

Nation (2001) pronounces that knowing the word implies knowing the individual from the group of the word and by creating capability, the quantity of the individuals from this word family will increase. Nourie and Davidson (1992) express that one of the useful methods of word construction in English is affixations. When Affixation is added to another one, it shapes one part of speech and this is a vital function of it; furthermore, in the second function, the meaning of lexical in the same part of speech could be changed.

According to Kress (1998), the visual mode is very important; because the dominance of images in the modern word is increasing through media, which can make and express them directly. Moreover, Baggett (1989) says that the images which have more cognitive pegs are stored in memory and it can be used to make cooperative and referential association between the information held in long term memory and visual representations.

Several studies have been done to find out the effect of affixes and it is believed that affixes are really crucial for learners. For instance, Graves (2004) states that word learning strategy which is related to morphological awareness are effective in order to improve English. Moreover, no research has been done in literature to find the reason of this problem exactly, and it is not clear if this strategies are enough for student or not, and if these images are able to help students to learn better. Consequently, the purpose of this study is to shed lights on this issue.

\section{REVIEW OF THE RELATED LITERATURE}




\section{A. The Importance Vocabulary}

In the universal research plan, vocabulary achievement has gotten little consideration (Lawson \& Hogben, 1996; Nation, 1993, 2001). Conversely, according to some research in the skill domain, communication is more suitable for vocabulary achievement rather than grammar (Rott, 1999; Vermeer, 1992). In fact, when people do not use the right words, it hinders communication (Allen, 1983, p. 5). Learning of vocabulary is crucial for language learning and language use and it is an essential part of language teaching is vocabulary learning (Laufer, 1997).

\section{B. Affixation}

For the sorts of formatives affixation is the collective term that can be utilized just when added to another morpheme (the root or stem), i.e. a sort of bound morpheme are affixes. Affixes are classified into two types depending on the root or stem of the word. In fact, Those that are added to the front of the root or stem is prefixes, e.g. "dis-" in "disable", and those which follow root or stem are called suffixes, e.g. "-ness" in "sickness". Thus, based on Crystal (1985), the morphological process, whether grammatical or lexical which is added to a stem is known as affixation (prefixation and suffixation). The familiarity with prefixes and suffixes is important in the acquisition of English as a foreign language (Monson, 1968). It helps students to learn English better. It is easier to improve vocabulary by becoming familiar with frequent prefixes and suffixes, than by memorizing each word separately. If the words are classified by similar meanings and the same word-class, they are memorized better than if arranged alphabetically (Thakur, 1997).

\section{Learning Strategies}

Since the 1970s, most attention has been given to the role of strategies in L2 learning (O'Malley \& Chamot, 1990; Oxford, 1993). According to (Brown, 2007), Strategies are those specific "action" that one can make on a given problem, and they are various in each person. Chamot (2005) characterizes strategies extensively as "techniques that help a learning assignment. Strategies are regularly conscious and objective driven" (p. 112).

Weinstein and Mayer (1986) considered learning strategies (LS) as "Behaviors and thoughts that a learner takes part in learning which are planned to impact the learner's encoding procedure" (p. 315). Based on this definition, the process is changing from teacher centered to learner-centered instruction in foreign language teaching and learning. There are different ways in order to enhance the input. Using pictures and images is one of these strategies for learning English. Nelson, Reed, and McEvoy (1976) argue that memorizing by pictures or images is more beneficial than the words by themselves. Similarly, Koran (1997) states that in learning new words with pictures, the learner can learn easier and better than leaning the word without pictures. An important and suitable solution for many problems is visual elements such as pictures (Horn, 1998). Furthermore, Underwood (1989) has come to conclusion that visual memory plays an important role in learning. Mayer and Sims (1994) mentioned that through visual elements such as pictures or real objects words are learned better because in learning process, the use of pictures is easier and more effective. In addition, if learners learn and recollect vocabulary items through the utilization of visual materials, it can be more useful than learning vocabulary items without perception of visual materials (Armstrong, 2000).

\section{METHOD}

\section{A. Participants}

The participants of the present study were 60, Iranian female EFL learners, who were enrolling an EFL course in Mehr Language Institute in Tehran. In the first step a PET (Preliminary English Test) was conducted on 100 intermediate students. Having calculated the mean and the SD, participants with the score of $1 \mathrm{SD}$ above and below the mean $(1 \mathrm{SD} \pm$ mean) were selected to conduct the next step. After homogenizing learners based on PET, the chosen participants were randomly divided and assigned into control and experimental groups with 30 participants in each group. All the participants of the survey were 17 to 30-year-olds, who had studied English in junior-high and high school.

\section{B. Instruments}

\section{Preliminary English Test (PET)}

In order to measure the participants' general proficiency level a PET test was administrated. PET is considered as the second level of Cambridge ESOL exam and measures four language skills of speaking, writing, listening, and reading. The test includes three papers. It is worth mentioning that the speaking section of PET was not performed due to language school's limitation.

\section{Affixes Pretest}

In the begging of the treatment, a piloted teacher-made test including 30 multiple-choice items was administered among the participants. The test content was based on those affixes which were going to be taught during the treatment. The purpose of pretest was to make sure those participants were not familiar with these affixes and also to homogenize the participants in knowledge of the affixes.

3. Affixes posttest

At the end of the treatment, a piloted teacher-made post-test was administered in order to investigate the students' learning of affixes and the difference between the two groups. 


\section{Procedure}

Prior to instruction, the proficiency test, pretest and posttest of affixes were piloted on a group of 30 participants. The point of carrying out a pilot study is to test-often to revise-and then finalize the materials and the methods. Therefore, a group of 30 participants with the same characteristics of the participants in the control and experimental group were selected and the pretest and posttests were administered to them. Later on malfunctioning items were discarded and the reliability of the tests before and after discarding malfunctioning items was calculated. Also, the procedure of utilizing the selected images for teaching the respected affixes was piloted to fix any problems prior to the actual research study. First, PET (Preliminary English Test) was conducted on 100 intermediate students. Considering the mean and the SD, participants whose score was $1 \mathrm{SD}$ above and below the mean, were selected. After homogenizing learners based on PET, the chosen participants were randomly divided and assigned into control and experimental groups with 30 participants in each group, and then a pre-test of affixes was administered. As this course was a general English course, communicative Language Teaching was used in both classes and all methods except for affix instructions were the same. Throughout the course both groups studied affixes as a part of their vocabulary instruction. The participants in the control group were not given any special treatment and followed the activities in their course book. The participants in the experimental group, however, were taught the same affixes with the help of related images and using visual aids and pictures. By the end of the course a posttest of affixes was administered in both control and experimental groups to recognize the impact of the teaching methods.

\section{RESULT AND DiSCUSSION}

The first step in the process of participants' selection was piloting PET. Since the purpose of this study was to measure the writing ability of the participants, the speaking section of PET was excluded from PET. Following the piloting of the PET, the descriptive statistics of this administration were calculated with the mean and standard deviation standing at 53.26 and 10.185, respectively (Baradaran \& Alavi, 2015). Following the piloting, the PET was administered to 100 students with the aim of selecting 60 of them for the study. The descriptive statistics of this process are presented below in Table 1 with the mean and standard deviation being 55.70 and 7.28, respectively.

TABLE 1.

DESCRIPTIVE STATISTICS FOR PET PROFICIENCY TEST

\begin{tabular}{l|l|l|l|l|l|l|l} 
& $\mathrm{N}$ & Minimum & Maximum & Mean & Std. Deviation & Kurtosis \\
\cline { 2 - 8 } & Statistic & Statistic & Statistic & Statistic & Statistic & Statistic & Std. Error \\
\hline PET admin & 100 & 35.50 & 69.50 & 55.7000 & 7.28836 & .637 & .457 \\
\hline Valid N (listwise) & 100 & & & & & &
\end{tabular}

Out of the 100 participants, 60 whose scores fell between one standard deviation above and below the mean were chosen and randomly assigned into two groups (i.e. control and experimental groups). Before the treatment started, the teacher-made test of affixes was piloted among 30 learners bearing almost the same characteristics of the sample. The descriptive statistics of this administration were calculated with the mean and standard deviation standing at 20.46 and 3.93, respectively. Following the piloting of the test, item analysis was done. Item facility measures fell between .16 and .56 and item discrimination amounts ranged from .11 to .42. Therefore, there was no mal-functioning item; and thus, no need to have revision on any of the items. Finally, the reliability of the test scores gained by the participants at the piloting phase - using Cronbach Alpha- was calculated to be 0.87. Following the piloting of the test of affixes, the test was administered to the participants. Table 2 shows the descriptive statistics resulted from the test.

TABLE 2.

\begin{tabular}{|c|c|c|c|c|c|c|c|}
\hline \multicolumn{8}{|c|}{ DESCRIPTIVE STATISTICS ON PRETEST OF AFFIXES IN BOTH GROUPS } \\
\hline & $\mathrm{N}$ & Minimum & Maximum & Mean & Std. Deviation & Skewness & \\
\hline & Statistic & Statistic & Statistic & Statistic & Statistic & Statistic & Std. Error \\
\hline Control Pretest & 30 & 8.00 & 16.00 & 10.9000 & 2.38313 & .733 & .427 \\
\hline Experimental Pretest & 30 & 8.00 & 15.00 & 10.6333 & 1.88430 & .772 & .427 \\
\hline Valid N (listwise) & 30 & & & & & & \\
\hline
\end{tabular}

Before the treatment started, in order to make sure that the participants in two groups do not have pre-superiority over each other regarding the knowledge of affixes, an independent samples t-test was performed. And the results indicate that there is no significant initial difference in the knowledge of affixes between the two groups' learners. So the changes in posttest can be attributed to the treatment. 
TABLE 3.

INDEPENDENT SAMPLES T-TEST ON THE RESULT OF PRETEST

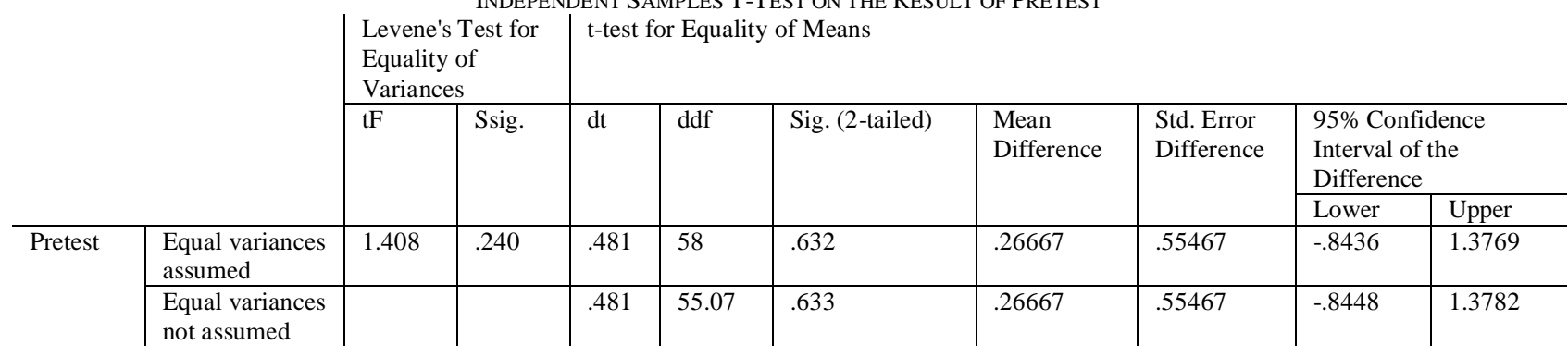

The researcher administered the same test of affixes at the end of the treatment as the posttest. Followings are the descriptive statistics obtained from the results.

TABLE 4.

DESCRIPTIVE StATISTICS ON THE PostTest RESUlts IN BOTH GROUPS

\begin{tabular}{l|l|l|l|l|l|l|l} 
& \multicolumn{6}{c}{ DESCRIPTIVE STATISTICS ON THE POSTTEST RESULTS IN BOTH GROUPS } \\
\cline { 2 - 8 } & Statistic & Statistic & Statistic & Statistic & Statistic & Skewness \\
\hline Control Posttest & 30 & 12.00 & 25.00 & 16.7333 & 3.52267 & .278 \\
\hline Experimental Posttest & 30 & 19.00 & 30.00 & 24.1000 & 3.39726 & .427 \\
\hline Valid N (listwise) & 30 & & & & & .427 \\
\end{tabular}

To test the null hypothesis of the study (the strategy of applying images does not have any significant effect on the EFL learners' knowledge of affixes) the researcher conducted an independent samples t-test procedure. As both distributions manifested normality with their skewness ratios $(0.278 / 0.427=0.651 ; 0.411 / 0.427=0.963)$ falling between the acceptable \pm 1.96 range, running an independent samples t-test was legitimized (table 5).

TABLE 5.

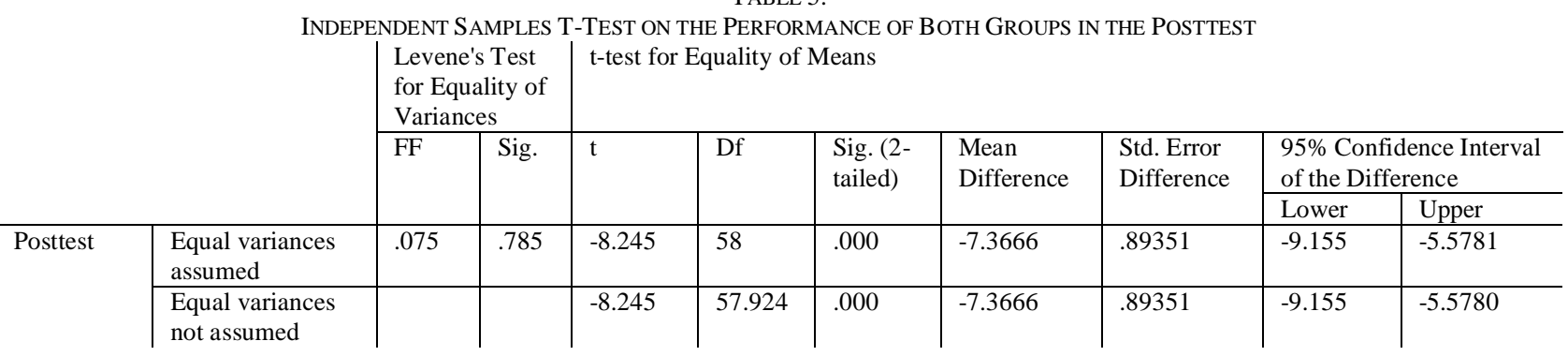

As is evident in Table 5 above with the $\mathrm{F}$ value of 0.075 at the significance level of 0.785 being larger than 0.05 , the variances between the two groups were not significantly different. The results $(t=8.245, \mathrm{p}=0.000<0.001)$ indicate that there is a significant difference between the mean scores of the two groups at the final exam. Thus, it is concluded that the participants of the experimental group strongly outperformed the control group in the final exam.

\section{CONCLUSION}

\section{A. Findings}

The findings indicated that the use of these strategies helped the learners to learn and remember the affixes. The results of the affix post-tests strongly revealed that learning the words through this strategy was effective and efficient. Furthermore, the participants who were exposed to treatment enhanced knowledge of the affixes. Similarly, regarding the results of data analysis, it can be concluded that there was a significant difference between two groups on learning vocabulary through affixes. In fact the one which exposed to applying images as their treatment performed better. This study is in line with Shin and Milroy (2000) who argued that morphemes have strong effect on the acquisition of English. Studying vocabulary with affix systems or patterns would seem to be much more effective language learners than just memorizing words. The finding of this study is in line with Konomi (2014) who examine the use of visual materials in teaching English vocabulary in grade 3 and 6. It is believed that some instruments such as images, pictures, postcards, word calendars, realia, graphs, graphic organizers, picture books, television, videos from iTunes, and computers, could be considered as an effective way to improve Young learners' performance in learning English. However, the findings of the present study are assumed to support Krashen's (1982) view that the important and suitable condition for L2 acquisition is the comprehensible input, and there is no need for formal instruction. The finding of the present study supports the one conducted by Carpenter and Olson (2012) who scrutinized the impact of teaching new vocabularies through pictures, and their findings proved that the students had positive attitudes towards using the pictures. Consequently, the finding of the current study showed that images are considered as an effective 
method in the development of affixes in EFL learners. Similarly, this study is also in line with the study done by Stokes (2002, as cited in Rokni \& Karimi, 2013) who studied the effect of using pictures in teaching vocabulary. She felt that pictures attracted the students' attention for better learning. She also felt that when students associate new words with a picture, it is easy for them to remember the meaning of the words.

\section{B. Applications and Implications}

The finding of the present study is also beneficial for teachers to integrate suitable and useful methods for teaching of vocabulary in their teaching courses. This way, teachers themselves would be educated of different vocabulary teaching techniques and will develop positive attitudes toward the mixture of the best techniques into their conventional teaching programs. Moreover, when the learner is conscious about affixes he or she is prepared well in learning new words, which is exactly what will happen in an independent learning processes. Even though learners don't know the vocabulary they can separate it and comprehend it. Using this way, they can do less work and the performance will be better. The affix development benefits the vocabulary learning since the vocabulary is one of the main parts on second language learning in order to learn vocabulary well. Besides, using affixation strategies has another advantage, which helps learners expand their knowledge of meaning. It is thus recommended that more affixes exercised can be applied in a lesson to enhance students' vocabulary learning. Because of this, EFL textbook designers, and materials developers should choose pictures; that is, pictures should match the text to assist students in learning.

\section{Suggestions for Further Research}

Other kinds of learning strategies could be investigated to find out if there is a best strategy suited for use in teaching learning of the affixes and as a result vocabulary learning. This research was carried out among younger EFL learners; the same experiment could be implemented among other age groups to see whether age is a factor in comparing the impact of applying images in teaching affixes. Only female students participated in this research; it would be interesting to see whether gender is also a factor in comparing the impact of using images on learning affixes.

\section{REFERENCES}

[1] Allen, F. V. (1983). Techniques in teaching vocabulary. Oxford: Oxford University Press.

[2] Armstrong, T. (2000). Multiple intelligences in the classroom. Alexandria, VA: ASCD.

[3] Baradaran \& Alavi. (2015). International Journal of Language Learning and Applied Linguistics Word (IJLLALW). Volume 8(2), February 2015.13-24.

[4] Baggett, P. (1989). Understanding visual and verbal messages. In H. Mandl \& J. Levin (Eds.), Knowledge acquisition from text and pictures (pp. 101-124). Amsterdam, The Netherlands: Elsevier

[5] Brown, D. H. (2007). Principles of language learning and teaching $\left(5^{\text {th }}\right.$ ed.). Pearson: Longman.

[6] Bauer, L., \& Nation, P. (1993). Word families. International Journal of Lexicography, 6(4), 253- 279.

[7] Carpenter, S. K., \& Olson, K. M. (2012). Are pictures good for learning new vocabulary in a foreign language? Only if you think they are not. Journal of Experimental Psychology, Learning, Memory, \& Cognition, 38(3), 92-101.

[8] Crystal, D. (1985). A dictionary of linguistics and phonetics (2nd ed.). New York: Basil Blackwell.

[9] Chamot, A. U. (2005). Language learning strategy instruction: Current issues and research. Annual Review of Applied Linguistics, 25(2), 112-130.

[10] Decarrico, J. S. (2001). Vocabulary learning and teaching. In M. Celce-Murcia (Ed.), Teaching English as a second or foreign language (3rd ed.) (pp. 285-299). Boston: Heinle \& Heinle.

[11] Graves, M. F. (2004). Teaching prefixes: As good as it gets? In J. F. Baumann, \& E. J. Kame'enui (Eds.), Vocabulary instruction: Research to practice (pp. 81-99). New York: Guildford Press

[12] Horn, R. (1998). Visual language: Global communication for the 21st Century. Bainbridge Island, WA: Macro VU Press.

[13] Konomi, D. (2014). Using Visual Materials in Teaching Vocabulary in English as Foreign Language Classrooms with Young Learners. In International Conference: New Perspectives in Science Education. Albania: Fan S. Noli University.

[14] Koren, S. (1997). Quality versus convenience: Comparison of modern dictionaries from the researcher's, teacher's and learner's points of view. TESL-EJ, 2(3), 1-16.

[15] Krashen, S. (1982). Principles and practice in second language acquisition. Oxford: Pergamon Press

[16] Kress, G. (1998). Visual and verbal modes of representation in electronically mediated communication: The potentials of new forms of text. In I. Snyder (Ed.), Page to screen: Taking literacy into the electronic era (pp. 53-79). New York, NY: Routledge

[17] Lawson, M. J., \& Hodben, D. (1996). The vocabulary-learning strategies of foreign-language students. Language Learning, 46(1), 101-35

[18] Laufer, B. (1997). The development of L2 lexis in the expression of the advanced learner. The Modern Language Journal, 75 , (4), 440-448.

[19] Milroy, J. (2000). Historical description and the ideology of the standard language. In L. Wright (Ed.), The development of standard English (pp. 11- 28). Cambridge: Cambridge University Press.

[20] Monson, L. A. (1968). Protective coatings for depression- strengthened nickel. In G. S. Ansell, T. D. Cooper, \& T.V. Lenel (Eds,.), Oxide depression strengthening (vol. 47)(pp. 563- 607). New York: Gordon \& Breach.

[21] Nation, I. S. P. (1990). Teaching and learning vocabulary. Massachusetts: Newbury House.

[22] Nation, I. S. P. (1993). Using dictionaries to estimate vocabulary size: essential, but rarely followed, procedures. Language Testing, $10(1), 27-40$.

[23] Nation, I. S. P. (2001). Learning vocabulary in a foreign language. Cambridge: Cambridge University press. 
[24] Nourie, B. L., \& Davidson, R. A., Jr. (1992). Vocabulary enrichment: Technology to the rescue! TESL Canada Journal, 12(1), 69-80.

[25] Nelson, D. L., Reed, V. S., \& Walling, J. R., (1976). Pictorial superiority effect. Journal of Experimental Psychology: Human Learning and Memory, 2(2), 523-528.

[26] Oxford, R. (1990). Language learning strategies: What every teacher should know. Newbury House, Boston.

[27] Oxford, R. L. (1993). Research on second language learning strategies. Annual Review of Applied Linguistics, 13(3), 175-187.

[28] O'Malley, J. M., \& Chamot, A. U. (1990). Learning strategies in second language acquisition. New York: Cambridge University Press.

[29] Rokni, S. J. A., \& Karimi, N. (2013). Visual Instruction: An Advantage or A Disadvantage? What about Its Effect on EFL Learners' Vocabulary Learning? Asian Journal of Social Sciences and Humanities, 2(4), 236-243.

[30] Rott, S. (1999). The effect of exposure frequency on intermediate language learner's incidental vocabulary acquisition and retention through reading. Studies of Second Language Aqcuisition, 2(3)1, 589-619.

[31] Scalise, S. (1984). Generative morphology. Holland, Dordrecht: Foris Publications.

[32] Shin, S. J., \& Milroy, L. (2000). Conversational codeswitching among Korean-English bilingual children. The International Journal of Bilingualism, 4(3),351-383.

[33] Stokes, S. (2002). Visual Literacy in Teaching and Learning: A Literature Perspective. Electronic Journal for the Integration of Technology in Education, 1(1), 10-19.

[34] Thakur, D. (1997). Linguistics simplified: Morphology. Patna: Bharati Bhawan Publishers \& printers.

[35] Thornbury, S. (2002). How to teach vocabulary. London: Longman.

[36] Underwood, J. (1989). Hypercard and interactive video. CALICO, 6(3), 7-20.

[37] Vermeer, A. (1992). Exploring the second language learner lexicon. In L. Verhoeven, \& J. DeJong (Eds), The construct of language proficiency (pp.147- 162). Amsterdam, Philadelphia: John Benjamins.

[38] Weinstein, C., \& Mayer, R. (1986). The teaching of learning strategies. In M. C. Wittrock (Ed.), Handbook of research on teaching, (3rd ed.)(pp. 315-327). New York: Macmillan.

[39] Wei, M. (2007). An examination of vocabulary learning of college-level learners of English in China. Retrieved on August 2013, from http://www.asian-efl-journal.com.

[40] Wenden, A. (1991). Learner strategies for learner autonomy: Planning and implementing learner strategy training for language learners. N.J.: Prentice Hall.

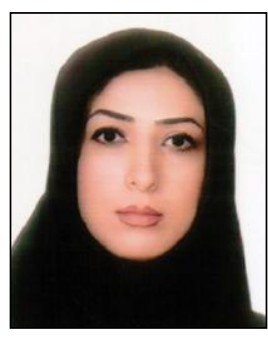

Fatemeh Sadat Nodjoomi is an English teacher at Tehran high schools and institutes. She received her M.A in English Teaching from Rudehen University. Her research areas include teacher education and vocabulary teaching.

Ahmad Yaghoubi is an assistant professor in TEFL at the Department of English Language Teaching of Roudehen Islamic Azad University. His areas of interest include issues in foreign and second language teaching and learning. 